\title{
Recovery of a subtidal soft-sediment macroinvertebrate assemblage following experimentally induced effects of a harmful algal bloom
}

\author{
Kerstin Kröger ${ }^{1,2, *}$, Jonathan P. A. Gardner ${ }^{1}$, Ashley A. Rowden ${ }^{2}$, Robert G. Wear ${ }^{1}$ \\ ${ }^{1}$ Island Bay Marine Laboratory, School of Biological Sciences, Victoria University of Wellington, PO Box 600, Wellington 6140, \\ New Zealand \\ ${ }^{2}$ Present address: National Institute of Water and Atmospheric Research, PO Box 14-901 Kilbirnie, Wellington 6241, \\ New Zealand
}

\begin{abstract}
A defaunation experiment mimicking the effects of a harmful algal bloom (HAB) on benthic macroinvertebrate assemblages $(>500 \mu \mathrm{m})$ was conducted at a hydrodynamically active soft-substrate site in Wellington Harbour, New Zealand, to test the recovery rate (return to predisturbance state) of temperate benthic macroinvertebrate assemblages and to elucidate the main factors influencing the recovery process. Tarpaulins were used to create anoxic conditions by smothering the sediment for $65 \mathrm{~d}$. Assemblage recovery in treatment plots was studied for $1 \mathrm{yr}$ and compared with assemblage composition in undisturbed adjacent control plots. Recovery was slow until Day 70, at which time abundance of individuals $(N)$ and number of species $(S)$ increased synchronously in treatments and controls. Within $10 \mathrm{mo}$, univariate indices $\left(N, S\right.$ and also species diversity $H^{\prime}$ and evenness $J^{\prime}$ ) of treatment assemblages returned to values observed for the control assemblages. Multivariate analyses showed that fluctuations in assemblage composition were most pronounced in the first $100 \mathrm{~d}$ in treatment replicates, but decreased thereafter as the recovering assemblage became more similar to the undisturbed one. However, after $1 \mathrm{yr}$, even though the composition of treatment and control assemblages was converging, differences in composition were still significant. Based on the observed trajectory of recovery, complete assemblage recovery is predicted to take approximately 2 yr. Timing of the disturbance in relation to seasonal recruitment events was identified as an important factor for assemblage recovery.
\end{abstract}

KEY WORDS: Benthic community · Macroinvertebrate assemblage · Disturbance • Recovery · Soft substrate $\cdot$ Multivariate analyses $\cdot$ Wellington Harbour $\cdot$ New Zealand

\section{INTRODUCTION}

A disturbance can be defined as 'any relatively discrete event in time that disrupts ecosystem, community, or population structure and changes resources, substrate availability, or the physical environment' (Pickett \& White 1985, p. 7). The extent, frequency and magnitude of disturbances vary depending on the nature of the disturbance (Thistle 1981), with the result that disturbances act at variable temporal and spatial scales. The importance of disturbances as a major structuring force in marine hard- and soft-sediment macroinvertebrate communities is well recognized (Dayton 1971), and such communities are often viewed as mosaics of patches, with each patch being at a different stage of recovery (Johnson 1973).

Large-scale partial or complete defaunation of benthic sediments resulting from naturally occurring disturbances (e.g. Leppäkoski 1968, Santos \& Simon 1980) have occurred throughout geological time (Diaz \& Rosenberg 1995). Nowadays, a growing number of seafloor areas are subject to defaunation as a consequence of anthropogenic disturbances (e.g. Pearson \& Rosenberg 1976, Saiz-Salinas 1997). Such 
defaunations are of wide-reaching consequence for ecosystem functioning, particularly in shallow coastal areas where benthic macroinvertebrates are of vital importance as food for fish species, many of which are exploited commercially (Beukema et al. 1999).

Benthic macroinvertebrate assemblages tend to recover from partial or complete defaunation due to natural, anthropogenic and experimental disturbances to a state similar to that of assemblages in adjacent undisturbed sediments (Thrush \& Whitlach 2001). Indeed, much of the evidence assembled from aquatic temperate systems points to recovery periods of $<3 \mathrm{yr}$ (Niemi et al. 1990). Hence, benthic macroinvertebrate assemblages generally exhibit high resilience (= short periods of time required to return to equilibrium) towards disturbance. However, recovery might also lead to a state where the recovered assemblage differs from the original one, depending on the disturbance history of the assemblage, the spatial and temporal scales (O'Neill 1999) and timing of the disturbance (Thrush \& Whitlach 2001). Current models of recovery processes in soft-sediment assemblages predict such processes via a specific sequence of successional stages tending towards higher system complexity (Pearson \& Rosenberg 1976, 1978, Rhoads et al. 1978). These models are often limited in their applicability because they do not generally account for the frequently observed variability in recovery processes (Zajac \& Whitlach 1982, Smith \& Brumsickle 1989). Such variability is foremost due to the influences of seasonality (Ford et al. 1999), hydrodynamics (Günther 1992), mobility of recolonising species (Whitlach et al. 1998, Thrush \& Whitlach 2001) and biotic interactions (Rhoads 1974) on the recovery processes. Specifically, benthic recovery processes following toxic plankton blooms in the Skagerrak-Kattegat area (Olsgard 1993) and in Wellington Harbour, New Zealand (Wear \& Gardner 2001, Kröger 2003, Kröger et al. 2006) did not reflect the predictions of the succession models mentioned, because a transient dominance of opportunistic species did not occur in the recovery processes. Additionally, current succession models do not take the spatial scale and intensity of the disturbance into account (Smith \& Brumsickle 1989, Norkko et al. 2006) and assume a state of complete defaunation caused by the disturbance (Zajac 1999, Platt \& Connell 2003).

On a small spatial scale, manipulative experiments detailing recovery processes after sediment defaunation have been reported (e.g. Snelgrove 1994), but difficulties arise when applying the results of these studies to larger spatial scales because factors controlling recovery are likely to be scale-dependent (Thrush et al. 1996, Whitlach et al. 1998). The extensive macrobenthic die-off caused by a bloom of the naked dinoflagellate Karenia brevisulcata in Wellington Harbour in
1998 operated at a relatively large spatial scale (Wellington Harbour $=\mathrm{ca} .85 \mathrm{~km}^{2}$, and much of it was affected), and although meso-scale (1 to $100 \mathrm{~m}^{2}$ ) manipulative experiments of benthic recovery processes have been conducted elsewhere (Thrush et al. 1996, Beukema et al. 1999, Dittmann et al. 1999), such experiments were situated on intertidal sand flats; thus, their applicability to subtidal recovery processes might be limited. To the best of our knowledge, no studies of meso-scale complete defaunations and their effects on benthic macroinvertebrate assemblages have been carried out in a temperate subtidal region. This is not surprising, given that manipulative experiments in the subtidal are difficult to conduct when the processes of interest are to be tested on large spatial and/or temporal scales.

Therefore, the need exists for experimental determination of recovery trajectories of subtidal macroinvertebrate assemblages following large-scale disturbances such as harmful algal blooms (HABs), especially in view of the increasing occurrence of such blooms on a global scale (Hallegraeff 1993). The present experiment, conducted in Wellington Harbour where subtidal macroinvertebrate assemblages were detrimentally affected by a toxic algal bloom in 1998 (for details see Chang et al. 2001, Wear \& Gardner 2001; for details of long-term assemblage recovery see Kröger et al. 2006), mimicked the effects of such a bloom on the benthos-i.e. mass mortality-but without actually creating a bloom. Smothering of the sediment surface was used to induce a benthic die-off that resulted from oxygen depletion, a common consequence of plankton blooms owing to the accumulation and decomposition of large amounts of organic matter in the form of phytoplankton and organisms killed by the bloom (Hallegraeff 1993).

Such an accumulation of organic matter was indeed observed following the Wellington Harbour toxic plankton bloom in 1998 (Wear \& Gardner 2001). Any toxic effect of this accumulation on infaunal macroinvertebrate assemblages would have been very short-lived due to the rapid disintegration of the neurotoxin after the bloom's collapse $(\mathrm{H}$. Chang pers. comm.); hence we feel our method of mimicking the effects of this HAB by smothering is justified. Thus, following an experimentally induced defaunation event, the present study aimed to test the hypothesis that benthic macroinvertebrate assemblage composition at a hydrodynamically exposed site changes in a sequential pattern over time, and that recovery is achieved in $1 \mathrm{yr}$. In the context of this experiment, complete recovery is defined as the state at which no significant differences can be detected in univariate diversity parameters (abundance $[N]$, number of 
species $[S]$, Shannon-Wiener's diversity index $\left[H^{\prime}\right]$, biomass) or in assemblage composition between the ambient undisturbed and the disturbed benthic macroinvertebrate assemblages. The testing of such a rapid rate of community recovery at the experimental site in Wellington Harbour is based on observations of high resilience among communities that experience frequent physical disturbances at inter- and subtidal hydrodynamically active sites (e.g. Schratzberger \& Warwick 1998), specifically in Wellington Harbour (Kröger et al. 2006).

\section{MATERIALS AND METHODS}

Study site. The experiment was located close to Matiu-Somes Island in Wellington Harbour, New Zealand $\left(41^{\circ} 15^{\prime} 33 \mathrm{~S}, 174^{\circ} 51^{\prime} 48 \mathrm{E}\right)$. Wellington Harbour is a temperate, semi-enclosed embayment (ca. $85 \mathrm{~km}^{2}$ ), linked in the south to coastal Cook Strait via a single channel. Mean water depth of the harbour is $14 \mathrm{~m}$, with a maximum depth of $32 \mathrm{~m}$ south-west and south-east of Matiu-Somes Island (Heath 1977). Tides are semi-diurnal and small with a maximum amplitude of $1.5 \mathrm{~m}$.

The experiment was initiated in the same season (austral autumn: March to May) as the 1998 toxic algal bloom, and in a section of the harbour where bloom cell concentrations had been high (Chang et al. 2001). The study site was shallow ( 7 to $9 \mathrm{~m}$ water depth) and relatively exposed to prevailing north-westerly winds. The extremely poorly sorted sandy sediment reported by Van der Linden (1967) for this area indicates a wind-driven high-energy wave regime. Preliminary diving examination of the study site revealed sandy sediment interspersed with small pebbles, whole shells and coarse shell fragments and some small boulders. Organic matter content was low at $1.9 \%\left( \pm 0.17 \mathrm{SD}_{;} \mathrm{n}=\right.$ 6 ; samples collected in January 2001 before commencement of experiment). The starfishes Patiriella regularis and Coscinasterias calamaria and the sea cucumber Stichopus mollis, all conspicuous surface dwellers, were commonly encountered during preliminary examination of the site.

Experimental set-up and sampling. Heavy plastic tarpaulins $(5 \times 5 \mathrm{~m})$ were used to cover each of 3 plots of sediment to prevent water flow over the sediment surface, thereby generating an anoxia-induced die-off of the benthos. The 3 tarpaulin-covered plots are referred to as 'treatments', whereas the 3 reference plots are referred to as 'controls'. Controls were of the same area as treatments, but received no tarpaulin cover. A linear systematic design was chosen to allocate sites as either treatments or controls, i.e. treatments alternated with controls. Plots were separated by $5 \mathrm{~m}$. Treatments were prepared by removing a small number of small boulders to facilitate a 'tight fit' of the tarpaulins over the sediment and to prevent their puncturing. Controls were prepared in the same way. Tarpaulins were rolled out on the treatment plots by divers on 11 January 2001 and were weighted down by anchor chains. The fit of the tarpaulins on the sediment was checked by divers 1 wk after set-up of the experiment and ca. fortnightly from then onwards. Tarpaulins were removed after 65 d on 6 April 2001, a period long enough to result in oxygen deficiency in the upper sediment layers.

Sampling times. Pre-disturbance biological samples were collected $1 \mathrm{~d}$ before the tarpaulins were deployed. However, these samples could not be analysed because residues of different samples were inadvertently mixed, thus ruling out any quality control. To permit detection of a peak of abundance of opportunistic species in the initial recovery phase as predicted by various models of community recovery, sampling frequencies were high at the beginning of the experiment and then extended to longer intervals. Deteriorating weather immediately after removal of the tarpaulins prevented us from determining whether the sediment was anoxic and if defaunation had occurred. Thus, the first samples were taken ca. $24 \mathrm{~h}$ after removal of the tarpaulins (Day $1=7$ April 2001). Samples were subsequently collected on 10 separate occasions (Day $6=$ 12 April 2001, Day $18=24$ April 2001, Day $39=15$ May 2001, Day $70=15$ June 2001, Day $100=15$ July 2001, Day $156=9$ September 2001, Day $218=10$ November 2001, Day $319=19$ February 2002 and Day $378=$ 19 April 2002 after the initiation of the experiment).

Sediment analyses. Organic matter content of the sediment was measured to establish whether organic enrichment had occurred as a consequence of the benthic die-off (Hallegraeff 1993). Separate sediment core samples (core diameter $4.2 \mathrm{~cm}$, penetration depth $10 \mathrm{~cm} ; \mathrm{n}=4$ per plot) were taken on each sampling day (except on Day 70, due to deteriorating weather) adjacent to the biological samples. Around $25 \mathrm{~g}$ of sediment from the top of each core were homogenised, dried $\left(3 \mathrm{~d}, 60^{\circ} \mathrm{C}\right)$ and weighed, and the organic matter determined as percent loss on ignition $\left(24 \mathrm{~h}, 450^{\circ} \mathrm{C}\right)$.

Biological analyses. Diver-operated circular PVC corers (core diameter $7.5 \mathrm{~cm}$, penetration depth $11 \mathrm{~cm}$; $\mathrm{n}=4$ per plot per sampling occasion) were employed to obtain biological samples. To prevent potential edge effects (sediment might not have been as anoxic at plot edges as in centre), samples were taken haphazardly within a $2 \mathrm{~m}$ circumference of a central marker in each plot, i.e. the sampling area of each plot was ca. $12.6 \mathrm{~m}^{2}$. Care was taken to avoid areas where depressions in the sediment indicated previous sampling. Once on 
board the RV 'Raukawa Challenger', cores were transferred to pre-labelled ziplock plastic bags. In the laboratory, the samples were washed immediately through a $500 \mu \mathrm{m}$ mesh using seawater and fixed in a boraxbuffered formalin solution ( $6 \%$ ) for a minimum period of $24 \mathrm{~h}$. Samples were rinsed in freshwater before being transferred to $70 \%$ ethanol, to which Rose Bengal was added to aid the sorting process. While the use of a $500 \mu \mathrm{m}$ sieve meant that most larval and some post-larval stages were not retained, the retention of all biota $>500 \mu \mathrm{m}$ is considered sufficient to address the questions of rate and trajectory of assemblage recovery.

Specimens were identified to the lowest possible taxonomic level. Where identification to species level was not possible, the concept of 'morphospecies' was employed (morphologically distinct individuals were treated as distinct species). Specimens were counted and their dry-blotted alcohol wet weight recorded to an accuracy of $\pm 0.001 \mathrm{~g}$. If the biomass was too small to be registered by the balance, a nominal weight of $0.001 \mathrm{~g}$ was automatically recorded for the particular specimen(s). Molluscs were weighed with their shell. A reference collection of all species encountered in the samples was established to aid in consistency of identifications.

Data analyses. Univariate analyses: The following diversity indices were calculated for each core sample using the software package PRIMER (Clarke \& Gorley 2001): abundance $(N)$, number of species $(S)$, Shannon-Wiener diversity index $\left(\log _{e}\right)\left(H^{\prime}\right)$ and Pielou's evenness index $\left(J^{\prime}\right)$. Univariate analysis was used to determine differences in these indices between control and treatment plots over time and in $\%$ organic matter (\%OM) (STATISTICA 7.0). Data (averaged per plot) were checked for ANOVA assumptions of normality (Shapiro-Wilks test) and homoscedasticity of variances (Cochran's test). Where assumptions were violated, analyses were conducted on rank-transformed data. Percentage data (\%OM) were arcsine-transformed. A 2-factorial ANOVA model with the categorical factors 'treatment' and 'sampling day' was used in order to investigate differences between control and treatment plots over time $(\mathrm{p}<0.05)$. Whenever a significant interaction term occurred, differences between controls and treatments were investigated for each sampling day separately using Tukey's Honestly Significant Difference (HSD) tests.

Multivariate analyses: PRIMER was also used for multivariate analyses of macroinvertebrate assemblage composition. Two treatment samples with 0 abundance (Days 1 and 6) were omitted from such analyses because the similarity between 2 samples with 0 abundance is not defined. Relative production
$(P)$, a combination of abundance $(N)$ and biomass $(B)$, is an especially suitable response unit to environmental perturbation (Clarke \& Warwick 2001) and was approximated using the allometric equation:

$$
P=(B / N)^{e} \times N
$$

where $e$ is the average exponent of the regression of annual production on body size for different phyla of macrobenthic invertebrates $(e=0.88$ for polychaetes, 0.64 for crustaceans, 0.72 for molluscs and 0.73 for the remaining taxa) (Brey 1990). For all multivariate analyses, production data were 4th-root transformed, allowing a wider view of the assemblages by decreasing the influence of numerically- or biomass-dominant taxa (Clarke \& Green 1988, Olsgard et al. 1997). Biomass is often highly spatially variable, and thus data incorporating biomass require a more severe transformation (Clarke \& Warwick 2001).

Non-metric multidimensional scaling (MDS) ordinations were plotted for control and treatment assemblage samples (averaged for each sampling day) and the sample points were linked in temporal order to visualise the degree of seriation, i.e. recovery. Two-way crossed analysis of similarity (ANOSIM; Warwick et al. 1990) was performed to test for significant differences in macroinvertebrate assemblage composition between the a priori groupings of samples. Samples were allocated to the factors 'treatment' (with levels 'treatment' and 'control') and 'sampling day' (with levels 1, 6, 18, 39, 70, 100, 156, 218, $319,378)$. The null-hypotheses tested were $\left(H_{0} 1\right)$ no difference in macroinvertebrate assemblages between control and treatment plots, allowing for differences among sampling days, and $\left(H_{0} 2\right)$ no difference in macroinvertebrate assemblage composition among sampling days, allowing for differences between control and treatment plots. A 1-way ANOSIM analysis (Clarke \& Green 1988) was performed to determine whether complete assemblage recovery was achieved in treatment samples. The null hypothesis (no difference between control and treatment assemblages) was tested in pairwise comparisons of control and treatment samples for each sampling day.

Similarity percentage analysis (SIMPER; Clarke 1993) was employed to assess compositional similarity and dissimilarity for control and treatment assemblages (averaged for each sampling day), and to identify the main species contributing to any dissimilarity between control and treatment assemblages for (1) each sampling day and (2) consecutive sampling days (for treatment assemblages only). The Index of Multivariate Dispersion (IMD; Warwick \& Clarke 1993) calculates the relative difference in the variability of replicate samples between groups. The 
IMD was applied as a measure of disturbance stress following Warwick \& Clarke's (1993) underlying assumption that increased variability in the multivariate structure of faunal assemblages is a sign of perturbation. The Index of Multivariate Seriation (IMS; Clarke et al. 1993) was used to detect assemblage responses to such stress. Variability was expressed as relative dispersion for control and treatment assemblages for each sampling day, and as IMD for pairwise comparisons of control and treatment assemblages for every sampling day. The IMS (expressed as Spearman's rank correlation $\rho_{\mathrm{S}}$ ) was applied as a measure of the extent to which changes in control and treatment assemblages conform to a monotonic sequence of compositional change.

\section{RESULTS}

\section{Sediment analyses}

After removal of the tarpaulins, divers reported black surface sediment at the centre of the treatment plots, indicating anaerobic conditions. No signs of recent bioturbation were visible in the treatments; that is, although many burrows were present, no recently ejected, lighter coloured substrate was seen around these openings. Subsurface sediment taken from treatment plots was much darker in colour than sediment from control plots, the difference remaining visible until at least Day 156. Mean \%OM ranged between 1.8 and $2.4 \%$ (Fig. 1). No significant Treatment $\times$ Sampling day interaction occurred $(\mathrm{p}=$ $0.3887, \mathrm{df}=8, F=1.10$; Table 1 ), and $\% \mathrm{OM}$ was significantly higher in treatments than in controls $(\mathrm{p}<$ $0.001, \mathrm{df}=1, F=16.97$ ).

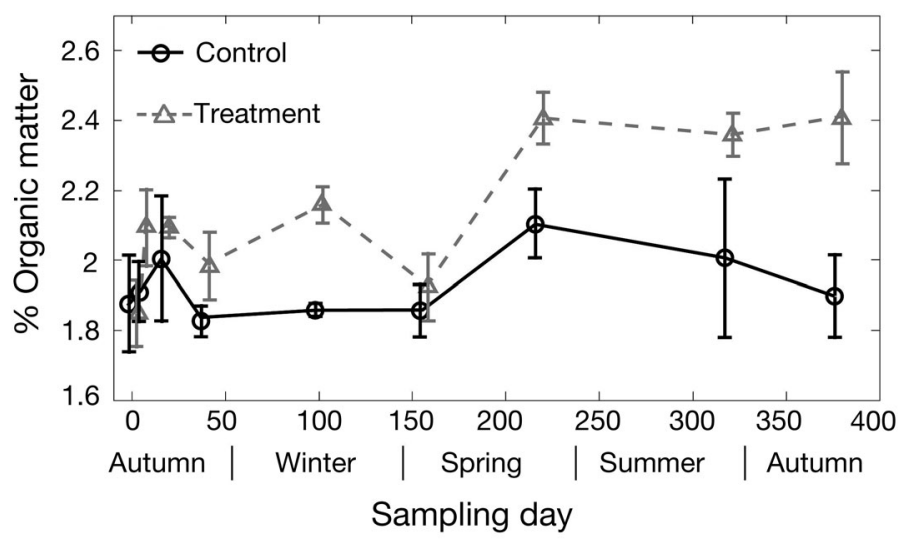

Fig. 1. Organic matter content (\%) for control and treatment samples. Values given are means of 3 sampling plots $( \pm \mathrm{SE})$. Control and treatment samples were taken on the same days (see 'Materials and methods') but symbols are slightly offset for ease of reading

\section{Biological analyses}

Overall, 15810 individuals belonging to 125 (putative) species were obtained from 228 core samples taken on 10 sampling occasions between April 2001 and April 2002. The majority of individuals (62.6\%) were found in controls. The overall total biomass of control and treatment samples was $589.3 \mathrm{~g}$, with $86.3 \%$ of the biomass extracted from control samples. Control and treatment samples contained a total of 110 species each, with 15 species encountered only in controls and 14 species only in treatments (see Appendix 1, available as Supplementary Material at www.int-res.com/articles/suppl/m326p085_app.pdf).

\section{Univariate diversity indices and species analyses}

The immediate effects of the experimentally induced disturbance were evident in the lower values of $N_{1} S$, biomass and $H^{\prime}$ and the higher values of $J^{\prime}$ in treatments compared to controls (Fig. 2). $N$ and $S$ increased in treatments from Day 70 onwards, whereas in controls an increase did not occur until Day 100. From Day 319 onwards, $N$ was higher in treatments than in controls. The change in $S$ was similar, with $S$ being lower in treatment plots until Day 218, when highest values for $S$ were recorded in both control and treatment plots. On Day 1 mean total biomass per core was ca. $85 \%$ lower in treatments than in controls, and remained low in treatments for the duration of the experiment. Variability in biomass among replicate samples was considerable in both controls and treatments, with high values being mainly caused by the occurrence of shelled molluscs such as Gari stangeri, Trochus tiaratus and Maoricolpus roseus roseus. $H^{\prime}$ generally displayed the same trend as $N$ and $S$, except that the maximum for $H^{\prime}$ was reached earlier in controls (Day 156) than in treatments (Day 218). $J^{\prime}$ was generally higher and changed to a greater extent in treatments than in controls. Whereas the decreasing values of $J^{\prime}$ in treatments from Day 156 onwards were indicative of the rising dominance of the actinian Scolanthus sp. and the polychaetes Owenia petersenae and Barantolla sp., $J^{\prime}$ was low in controls $(\sim 0.7)$ and varied little throughout the course of the experiment, indicating the continuous dominance of Barantolla sp. (Fig. 3).

Differences between control and treatments were highly significant for all 5 indices (Table 1). Significant interactions were detected for $N(\mathrm{p}<0.001, \mathrm{df}=9, F=$ 7.166), $S(\mathrm{p}<0.001, \mathrm{df}=9, F=8.418), J^{\prime}(\mathrm{p}=0.0201, \mathrm{df}=$ $9, F=2.56)$ and $H^{\prime}(\mathrm{p}=0.0013, \mathrm{df}=9, F=5.092)$, but not for biomass ( $\mathrm{p}=0.4572, \mathrm{df}=9, F=0.99)$. Thus, analyses for differences with time were conducted only for $N, S$, $H^{\prime}$ and $J^{\prime}$ (Table 1). Mean $N$ and $S$ were significantly 
Table 1. ANOVA results $(p<0.05)$ for effects of 'treatment' and 'sampling day' on \% organic matter (\% OM) abundance $(N)$, number of species $(S)$, biomass $(B)$, Shannon-Wiener's diversity index $\left(H^{\prime}\right)$ and Pielou's evenness index $\left(J^{\prime}\right)$. Where a significant interaction (Treatment $\times$ Sampling day) occurred, $\mathrm{p}$ value for each sampling day (control vs. treatment) is given. Data for $N, S$ and $J^{\prime}$ : rank-transformed; \%OM: arc-sine transformed

\begin{tabular}{|c|c|c|c|}
\hline $\begin{array}{l}\text { Variable } \\
\text { Factor }\end{array}$ & $\mathrm{p}$ value & $\begin{array}{l}\text { Sampling } \\
\text { day }\end{array}$ & $\mathrm{p}$ value \\
\hline \multicolumn{4}{|l|}{$\% \mathbf{O M}$} \\
\hline Treatment & 0.0002 & & \\
\hline Sampling day & 0.0141 & & \\
\hline Treatment $\times$ Sampling day & 0.3887 & & \\
\hline \multicolumn{4}{|l|}{$N$} \\
\hline Treatment & $<0.0001$ & 1 & 0.001 \\
\hline Sampling day & $<0.0001$ & 6 & 0.001 \\
\hline \multirow[t]{8}{*}{ Treatment $\times$ Sampling day } & $<0.0001$ & 18 & 0.290 \\
\hline & & 39 & 0.045 \\
\hline & & 70 & $<0.001$ \\
\hline & & 100 & 0.763 \\
\hline & & 156 & 0.184 \\
\hline & & 218 & 1.0 \\
\hline & & 319 & 1.0 \\
\hline & & 378 & 0.802 \\
\hline \multicolumn{4}{|l|}{$S$} \\
\hline Treatment & $<0.0001$ & 1 & 0.004 \\
\hline Sampling day & $<0.0001$ & 6 & 0.002 \\
\hline \multirow[t]{8}{*}{ Treatment $\times$ Sampling day } & $<0.0001$ & 18 & 0.731 \\
\hline & & 39 & 0.015 \\
\hline & & 70 & 0.006 \\
\hline & & 100 & 0.452 \\
\hline & & 156 & 0.069 \\
\hline & & 218 & 1.0 \\
\hline & & 319 & 1.0 \\
\hline & & 378 & 0.092 \\
\hline \multicolumn{4}{|l|}{$\boldsymbol{B}$} \\
\hline Treatment & $<0.0001$ & & \\
\hline Sampling day & 0.3012 & & \\
\hline Treatment $\times$ Sampling day & 0.4572 & & \\
\hline \multicolumn{4}{|l|}{$H^{\prime}$} \\
\hline Treatment & $<0.0001$ & 1 & 0.015 \\
\hline Sampling day & 0.0003 & 6 & 0.045 \\
\hline \multirow[t]{8}{*}{ Treatment $\times$ Sampling day } & 0.00013 & 18 & 0.459 \\
\hline & & 39 & 0.218 \\
\hline & & 70 & 0.147 \\
\hline & & 100 & 1.0 \\
\hline & & 156 & 1.0 \\
\hline & & 218 & 0.968 \\
\hline & & 319 & 1.0 \\
\hline & & 378 & 0.989 \\
\hline \multicolumn{4}{|l|}{$J^{\prime}$} \\
\hline Treatment & $<0.0001$ & 1 & 0.093 \\
\hline Sampling day & 0.0004 & 6 & 0.281 \\
\hline \multirow[t]{8}{*}{ Treatment $\times$ Sampling day } & 0.0201 & 18 & 0.631 \\
\hline & & 39 & 0.281 \\
\hline & & 70 & 0.058 \\
\hline & & 100 & 0.806 \\
\hline & & 156 & 0.991 \\
\hline & & 218 & 1.000 \\
\hline & & 319 & 0.979 \\
\hline & & 378 & 1.000 \\
\hline
\end{tabular}

lower in treatments until Day 70 (with the exception of Day 18), and mean $H^{\prime}$ ceased to be significantly lower after Day 6. For mean $J^{\prime}$, no significant differences could be detected. Owenia petersenae, Barantolla sp. and Scolanthus sp. were among the 5 most abundant species in both controls and treatments. Abundances of O. petersenae and Scolanthus sp. increased considerably in controls and treatments (Day 156), whereas Barantolla sp. occurred in high abundances in controls throughout the duration of the experiment (Fig. 3). Abundance patterns of Scolanthus sp. were similar in controls and treatments, with very low abundances until Day 100 and peak abundances at Day 218.

\section{Multivariate analyses}

MDS ordination revealed that macroinvertebrate assemblages of treatments, especially in the early phase of the experiment, were different from control assemblages (Fig. 4). Treatment samples displayed high variability, especially samples from Days 1 to 70 , whereas control samples formed a distinct cluster that exhibited comparatively little variation. From Day 156 onwards treatment samples were not only located closer together, but they were also located closer to control samples. However, treatment and control samples had not merged into a single cluster by Day 378. A 2-way crossed ANOSIM analysis showed that both factors, treatment and sampling day, had a significant effect on the macroinvertebrate assemblages, with treatment (global $\mathrm{R}=0.519$, $\mathrm{p}<0.001$ ) explaining more of the variation in the data set than sampling day (global $\mathrm{R}=0.320, \mathrm{p}<0.001$ ). Pairwise comparisons revealed that although differences between control and treatment assemblages decreased with time, recovery was not complete by Day 378, i.e. differences in assemblage composition between treatments and controls were still significant $>1 \mathrm{yr}$ after initiation of the experiment (Table 2). Recovery of the treatment assemblages is indicated by decreasing $\mathrm{R}$ values with time: the larger values expressing higher dissimilarities between control and treatment assemblages. The fluctuating $\mathrm{R}$ values in the early days of the experiment resulted from high variability in treatment assemblages.

While assemblage similarity remained relatively constant throughout the experiment for control assemblages, similarity for treatment assemblages was low until Day 70, but increased considerably between Day 70 and Day 100 (Table 3). From Day 156 onwards, treatment assemblages exhibited the same level of similarity as control assemblages.

Pairwise comparisons of control and treatment samples of the same sampling day indicated that 
assemblages were very different until Day 70 (high dissimilarities; 5 species explained $>30 \%$ of the difference between control and treatment assemblages), but dissimilarities decreased continuously between Day 100 and the end of the experiment (by Day 378, the top 5 species only explained $16.6 \%$ of the difference between control and treatment assemblages), indicating that control and treatment assemblages became more similar (Table 4).

Between Day 1 and Day 70, species responsible for the dissimilarities occurred mainly in control assemblages (e.g. Gari stangeri, Barantolla sp., Owenia petersenae; Table 4). Only from Day 100 onwards did species in treatment assemblages contribute to some extent to average dissimilarity. The capitellid Barantolla sp. and the oweniid $O$. petersenae continued to contribute consistently to the dissimilarity $(\delta)$ between control and treatment assemblages (indicated by a ratio of $\left.\delta_{i} / \mathrm{SD}\left(\delta_{i}\right)>1.3\right)$, whereas the taxa Gammaridae sp. B, Tawera spissa and Notomastus sp. (occurring in treatment plots) were also found to discriminate between the assemblages. From Day 319 onwards, a different set of species was responsible for assemblage dissimilarity (i.e. Phoronis sp., Euchone sp. A, Trochodota dendyi, Polycirrcus sp. A).

Average dissimilarity between treatment assemblages of consecutive sampling days remained relatively high $(\delta=\mathrm{ca} .80 \%)$ until between Day 100 and Day 156, when it decreased to $68.2 \%$ (Table 5). Dissimilarity decreased further as the experiment progressed, and by Day 319 had reached levels similar to dissimilarities between control and treatment assemblages on Day 319 and Day 378. Relatively few species contributed to dissimilarity between treatment assemblages of the early consecutive sampling days (until approximately Day 100), and the ratios of $\delta_{i} / \mathrm{SD}\left(\delta_{i}\right)$ remained $<1.3$. After Day 100 the number of contributing species increased considerably, but the individual contributions of species decreased, thus indicating increasing complexity of the assemblage.

Relative dispersion and IMD described clear differences in variability between control and treatment assemblages (Table 6). While control assemblages displayed a relatively constant level of dispersion throughout the experiment, treatment assemblages exhibited considerably higher dispersion values until Day 100. However, treatment assemblage dispersion values decreased and, by Day 156 or shortly thereafter, reached the same level of dispersion as control assemblages. The trend of converging dispersion values was also expressed in the IMD values. That is, pairwise comparisons of control and treatment assemblages of the same sampling day revealed that, from Day 156 onwards, variability in the multivariate structure of control and treatment assemblages was comparable.

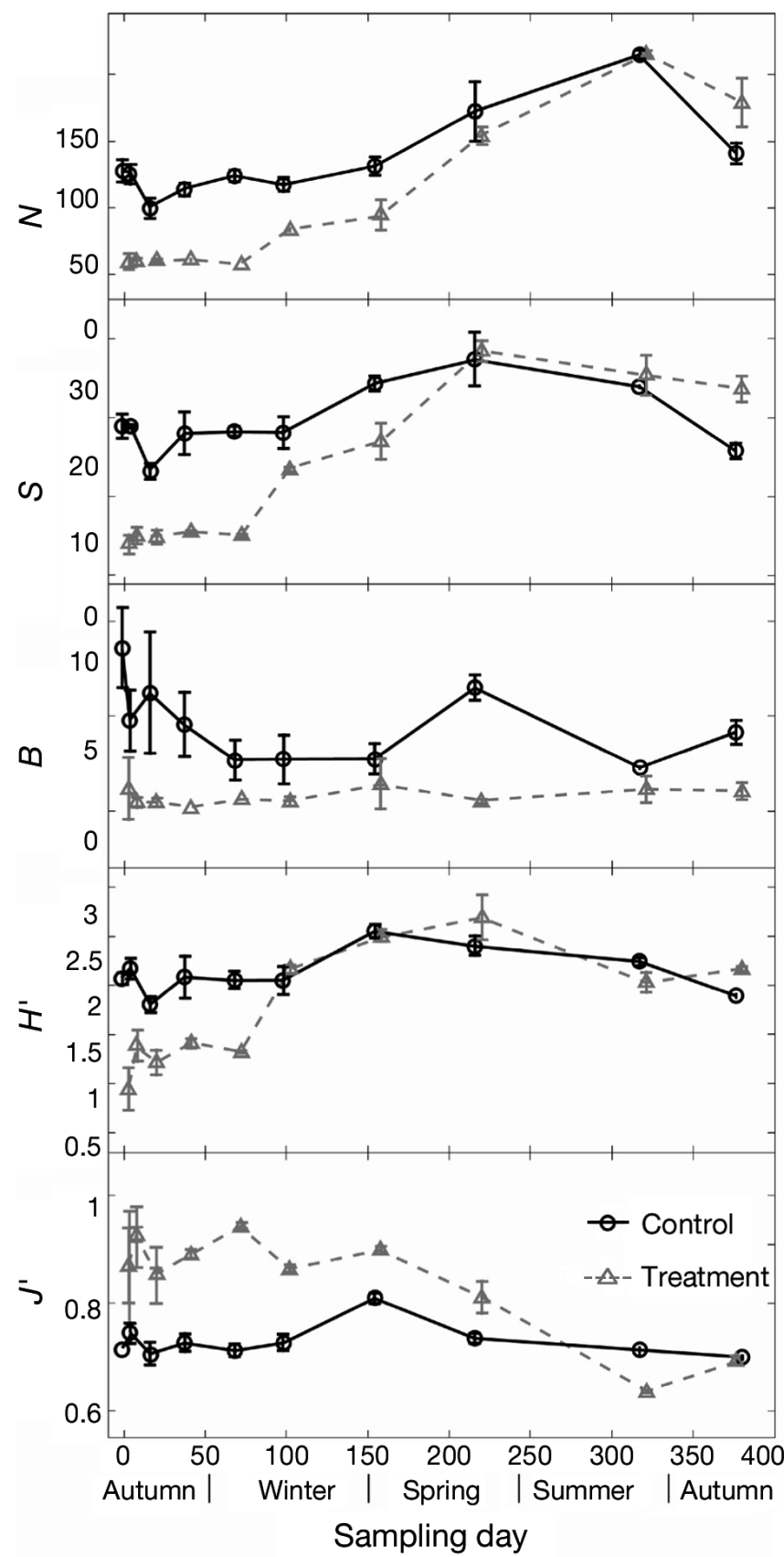

Fig. 2. Abundance of individuals $(N)$, mean number of species $(S)$, mean total biomass $(B)$ (per core), Shannon-Wiener's diversity index $\left(H^{\prime}\right)$ and Pielou's evenness index $\left(J^{\prime}\right)$ for control and treatment assemblages. Values given are means of 3 sampling plots $( \pm \mathrm{SE})$. Symbols are offset for ease of reading

Spearman's rank correlation coefficient for treatment assemblages indicated a strong sequential change in the composition of the faunal assemblage $(\rho=0.813, p=0.002$; number of permutated statistics $\geq$ $\rho=0$ of 5000), but this trend was not observed to the same extent in control assemblages $(\rho=0.484$ with $p=$ 0.04 ; number of permutated statistics $\geq \rho=18$ of 5000 ). 


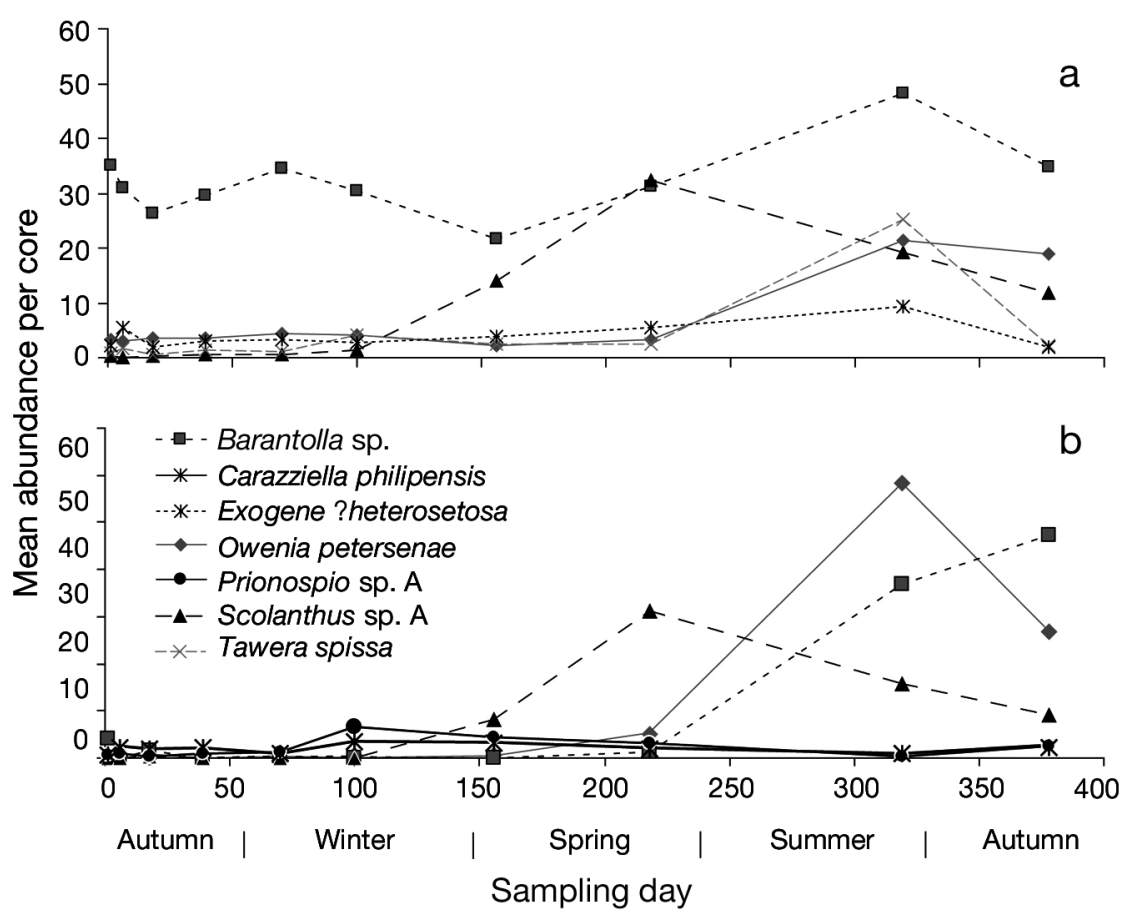

Fig. 3. Abundance of the 5 most numerically dominant taxa for (a) control and (b) treatment assemblages $(n=3)$. Values given are means per core; SE were omitted for clarity

\section{DISCUSSION}

The method used in the present study to mimic an HAB-induced benthic die-off was successful, given that macroinvertebrate abundances, number of species and biomass were much reduced in treatment compared with control plots after removal of tarpaulins. Complete mortality did not occur, i.e. the disturbance was non-catastrophic. This is a more realistic starting point for benthic recovery processes after a naturally occurring disturbance than a state of 'tabula rasa' (clean slate), which is assumed in most current succession models that explain directional species replacement (Platt \& Connell 2003).

The time required for a disturbed assemblage to recover completely and reach the same level of assemblage composition as the undisturbed surrounding assemblage depends on the criteria used to define complete recovery. According to the definition used in the present study, univariate indices of abundancebased parameters indicated a complete recovery of the assemblage in treatment plots for most indices after $<100 \mathrm{~d}_{\text {; }}$ for biomass and evenness, $J^{\prime}$ differences were not even significant on Day 1 of the experiment. Although not statistically significant, mean biomass in treatments remained lower than in controls for the duration of the experiment. Complete recovery of biomass can take as long as 1 turn-over of the most long-lived constituent species in the community (Connell \& Sousa 1983), in this case probably the sunset shell Gari stangeri. These univariate index results indicate that assemblage recovery was complete within $<1$ yr of experiment commencement: thus we initially accepted our first hypothesis that there was no difference in macroinvertebrate assemblages between control and treatment plots.

However, multivariate analysis revealed that, although some recovery had clearly occurred, control and treatment assemblages were still significantly dissimilar after $1 \mathrm{yr}$, and thus recovery was incomplete. Decreasing ANOSIM R values over time, decreasing dissimilarities and IMD values of same-day control and treatment assemblages indicated an on-going recovery process in which the disturbed assemblages showed increasing resemblance to the ambient control assemblages, thus confirming our hypothesis that changes in the assemblage composition would follow a sequential pattern. While the IMS supported the prediction of a sequential pattern of community recovery, the trajectories of control and treatment assemblages, even though converging towards the same location in the ordination plot, did not overlap after $378 \mathrm{~d}$. Our finding that a similar but not identical assemblage composition results post-disturbance is shared with most experimental defaunation studies, irrespective of the recov-

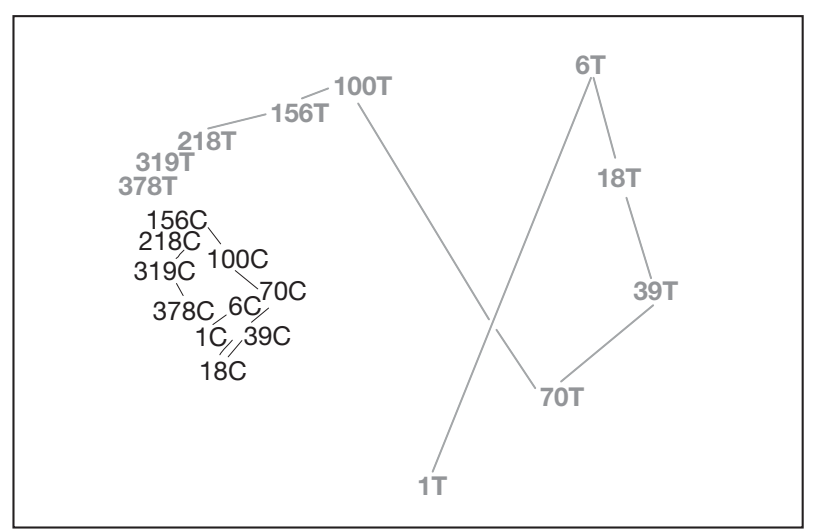

Fig. 4. Multi-dimensional scaling (MDS) ordination using Bray-Curtis similarities of 4 th-root transformed production data (approximated from abundance and biomass data following Brey 1990). Sample points linked in temporal order. Stress $=0.11$. Numerals $(1,6,18$, etc. $)$ : sampling day; $\mathrm{C}$ : control, T: treatment. $\mathrm{n}=8$ to 12 per sampling occasion. $1 \mathrm{~T}$ and 6T: 1 sample each omitted from analysis due to 0 abundance 
Table 2. ANOSIM pairwise comparisons of 4th-root transformed production data for control $(\mathrm{C})$ and treatment $(\mathrm{T})$ assemblages on each sampling day. 1, 6, 18 etc.: sampling day

\begin{tabular}{|lcc|}
\hline Groups compared & $\mathrm{R}$ & $\mathrm{p}$ \\
\hline $1 \mathrm{C}, 1 \mathrm{~T}$ & 0.537 & $<0.001$ \\
$6 \mathrm{C}, 6 \mathrm{~T}$ & 0.577 & $<0.001$ \\
$18 \mathrm{C}, 18 \mathrm{~T}$ & 0.519 & $<0.001$ \\
$39 \mathrm{C}, 39 \mathrm{~T}$ & 0.643 & $<0.001$ \\
$70 \mathrm{C}, 70 \mathrm{~T}$ & 0.528 & $<0.001$ \\
$100 \mathrm{C}, 100 \mathrm{~T}$ & 0.712 & $<0.001$ \\
$156 \mathrm{C}, 156 \mathrm{~T}$ & 0.531 & $<0.001$ \\
$218 \mathrm{C}, 218 \mathrm{~T}$ & 0.448 & $<0.001$ \\
$319 \mathrm{C}, 319 \mathrm{~T}$ & 0.329 & $<0.001$ \\
$378 \mathrm{C}, 378 \mathrm{~T}$ & 0.266 & 0.002 \\
\hline
\end{tabular}

Table 3. Average among-replicate similarity (\%) for control and treatment assemblages of 4th-root transformed production data

\begin{tabular}{|lcc|}
\hline Sampling day & Control & Treatment \\
\hline 1 & 46.51 & 17.21 \\
6 & 49.80 & 19.13 \\
18 & 43.69 & 15.96 \\
39 & 45.65 & 24.03 \\
70 & 50.43 & 17.21 \\
100 & 44.50 & 35.64 \\
156 & 40.50 & 40.89 \\
218 & 46.86 & 50.29 \\
319 & 50.62 & 46.98 \\
378 & 46.98 & 45.30 \\
\hline
\end{tabular}

ery time. Assuming that no other major disturbance interrupts the recovery process, we predict that recovery (as defined for the present study) will be completed after a second major recruitment event, i.e. ca. 2 yr after the experimental disturbance.

Total \%OM remained slightly higher in treatment plots from Day 6 until the end of the experiment. Whether this was due to more decaying matter and subsequently a higher bacterial biomass in treatments following the oxygen depletion, or due to the existence of larvae and post-larval stages too small to be detected by eye and thus not removed from the sediment samples, remains open. The higher \%OM levels in control and treatment plots from Day 156 onwards could also be caused by a seasonal increase in benthic diatoms or in phytoplankton accumulated on the sediment.

\section{Factors influencing recovery rate}

Recovery of benthic macroinvertebrate assemblages following a disturbance is determined by, among other factors, the spatial scale of the disturbance (Smith \&
Brumsickle 1989). Short recovery times ranging from hours to weeks have been reported for small-scale disturbances $\left(<1 \mathrm{~m}^{2}\right)$ (Bell \& Devlin 1983), whereas complete recovery following large-scale disturbances (>100 $\mathrm{m}^{2}$ ) requires several years (Gjøsæter et al. 2000). In the present study, where the scale of disturbance was $\sim 25 \mathrm{~m}^{2}$, recovery of abundance $(N)$ and number of species $(S)$ to levels of adjacent undisturbed assemblages took approximately 10 mo (even though differences ceased to be significant after only $70 \mathrm{~d}$ ). Similar results were reported in other meso-scale studies (1 to $100 \mathrm{~m}^{2}$ ), where recovery took between several weeks and several months, depending on the timing of the disturbance (Thrush et al. 1996). Soft-substrate intertidal communities typically recover much faster following spring or summer disturbances than following autumn or winter disturbances, with $N$ and $S$ returning to levels of the ambient undisturbed sediment almost as soon as recovery begins during spring or summer months (Zajac \& Whitlach 1982, Beukema et al. 1999, Dittmann et al. 1999). Recovery in the present study indicates that macroinvertebrate assemblages of subtidal soft sediments exhibited the typical pattern following a disturbance in autumn, with recovery not being perceptible until mid-winter and $N$ and $S$ not approaching ambient levels until the following summer. The high degree of recovery in spring and summer, when abundances increased synchronously in ambient and disturbed sediments, indicated that the recovery process was influenced by the same largescale factors (e.g. seasonal cycles in reproduction and mortality) that influenced the ambient assemblage, which provides a pool of potential colonists.

\section{Origins of colonisers}

Conceptual models predict that adult immigration is more important for recovery on small spatial scales, whereas larvae and post-larval stages are dispersed over larger spatial scales and are thus more important for recovery dynamics on such larger scales (Günther 1992). Recent model simulations suggest that species' life history traits also affect recovery processes (Whitlach et al. 2001). In this model, early successional species (typically opportunists) colonised mainly as larval stages, while species with life history traits of late successional stages predominantly entered the newly available sediments as juvenile and adult immigrants. In the context of the present study, the model simulations of Whitlach et al. (2001) imply that larval recruitment is of more importance in the observed recovery process than juvenile and adult immigration, due to the ambient assemblage that consists primarily of opportunistic species. Such species were the poly- 
Table 4. Average dissimilarity $(\delta)$ for each sampling day and species contributing most to $\delta$ for control (C) and treatment (T) assemblages. $1,6,18$, etc.: sampling day; $Y_{\mathrm{C}, \mathrm{T}}$ : average production of $i$ th species in sample groups $\mathrm{C}$ and $\mathrm{T}_{i} \delta_{i}$ : contribution of $i$ th species to $\delta_{i} \operatorname{SD}\left(\delta_{i}\right)$ : standard deviation; $\sum \delta_{i \%}$ : percent cumulative contribution to $\delta$. Taxa: $\mathrm{A}=$ Amphipoda; An $=$ Anthozoa; $\mathrm{B}=$ Bivalvia $; \mathrm{E}=$ Echinodermata $\mathrm{G}=$ Gastropoda $; \mathrm{P}=$ Polychaeta $; \mathrm{O}=$ Ostracoda. Only the 5 species contributing most are listed

\begin{tabular}{|c|c|c|c|c|c|c|c|}
\hline $\begin{array}{l}\text { Sampling day, } \\
\text { Site }\end{array}$ & $\delta$ & Species & Taxon & $y_{\mathrm{C}}$ & $y_{\mathrm{T}}$ & $\delta_{i} / \mathrm{SD}\left(\delta_{i}\right)$ ratio & $\Sigma \delta_{i \%}$ \\
\hline \multirow[t]{5}{*}{$1 \mathrm{C}, 1 \mathrm{~T}$} & \multirow[t]{5}{*}{84.27} & Gari stangeri & $\mathrm{B}$ & 3.69 & 0.55 & 0.97 & 8.89 \\
\hline & & Barantolla sp. & $\mathrm{P}$ & 0.21 & 0.14 & 1.67 & 16.10 \\
\hline & & Owenia petersenae & $\mathrm{P}$ & 0.13 & 0.01 & 2.24 & 22.23 \\
\hline & & Notomastus sp. & $P$ & 0.09 & 0.00 & 1.80 & 28.22 \\
\hline & & Dolasterope quadrata & $\mathrm{O}$ & 0.04 & 0.00 & 1.41 & 32.63 \\
\hline \multirow[t]{5}{*}{$6 \mathrm{C}, 6 \mathrm{~T}$} & \multirow[t]{5}{*}{87.37} & Barantolla sp. & $\mathrm{P}$ & 0.19 & 0.00 & 2.93 & 8.10 \\
\hline & & Gari stangeri & $\mathrm{B}$ & 2.08 & 0.00 & 0.75 & 14.51 \\
\hline & & Owenia petersenae & $\mathrm{P}$ & 0.05 & 0.00 & 2.54 & 20.42 \\
\hline & & Notomastus sp. & $\mathrm{P}$ & 0.12 & 0.00 & 1.73 & 26.18 \\
\hline & & Dolasterope quadrata & $\mathrm{O}$ & 0.03 & 0.00 & 2.40 & 30.95 \\
\hline \multirow[t]{5}{*}{$18 \mathrm{C}, 18 \mathrm{~T}$} & \multirow[t]{5}{*}{88.19} & Gari stangeri & $\mathrm{B}$ & 2.80 & 0.00 & 0.99 & 11.15 \\
\hline & & Barantolla sp. & $\mathrm{P}$ & 0.20 & 0.00 & 2.69 & 19.60 \\
\hline & & Notomastus sp. & $\mathrm{P}$ & 0.13 & 0.00 & 1.64 & 27.18 \\
\hline & & Owenia petersenae & $\mathrm{P}$ & 0.03 & 0.00 & 4.62 & 33.40 \\
\hline & & Hemipodus simplex & $\mathrm{P}$ & 0.03 & 0.00 & 1.61 & 38.31 \\
\hline \multirow[t]{5}{*}{ 39C, 39T } & \multirow[t]{5}{*}{86.04} & Barantolla sp. & $\mathrm{P}$ & 0.17 & 0.00 & 3.31 & 8.80 \\
\hline & & Notomastus sp. & $\mathrm{P}$ & 0.16 & 0.04 & 1.99 & 16.21 \\
\hline & & Gari stangeri & B & 1.70 & 0.00 & 0.77 & 21.83 \\
\hline & & Hemipodus simplex & $\mathrm{P}$ & 0.02 & 0.00 & 2.34 & 26.58 \\
\hline & & Owenia petersenae & $\mathrm{P}$ & 0.02 & 0.00 & 2.10 & 31.31 \\
\hline \multirow[t]{5}{*}{$70 \mathrm{C}, 70 \mathrm{~T}$} & \multirow[t]{5}{*}{86.13} & Barantolla sp. & $\mathrm{P}$ & 0.21 & 0.00 & 3.30 & 8.85 \\
\hline & & Notomastus sp. & $\mathrm{P}$ & 0.07 & 0.00 & 2.22 & 15.62 \\
\hline & & Gari stangeri & B & 1.24 & 0.00 & 0.79 & 22.12 \\
\hline & & Owenia petersenae & $\mathrm{P}$ & 0.03 & 0.00 & 1.95 & 26.88 \\
\hline & & Hemipodus simplex & $\mathrm{P}$ & 0.02 & 0.00 & 1.84 & 30.83 \\
\hline \multirow[t]{5}{*}{$100 \mathrm{C}, 100 \mathrm{~T}$} & \multirow[t]{5}{*}{74.85} & Barantolla sp. & $\mathrm{P}$ & 0.24 & 0.00 & 2.95 & 8.43 \\
\hline & & Notomastus sp. & $\mathrm{P}$ & 0.04 & 0.00 & 1.50 & 13.61 \\
\hline & & Scolanthus sp. & An & 0.05 & 0.00 & 1.47 & 17.97 \\
\hline & & Owenia petersenae & $\mathrm{P}$ & 0.02 & 0.00 & 1.91 & 21.36 \\
\hline & & Gammaridae sp. B & A & 0.02 & 0.02 & 1.12 & 24.37 \\
\hline \multirow[t]{5}{*}{$156 \mathrm{C}, 156 \mathrm{~T}$} & \multirow[t]{5}{*}{68.93} & Barantolla sp. & $\mathrm{P}$ & 0.10 & 0.00 & 2.78 & 5.08 \\
\hline & & Notomastus sp. & $\mathrm{P}$ & 0.07 & 0.00 & 1.61 & 9.08 \\
\hline & & Gari stangeri & B & 0.75 & 0.00 & 0.59 & 12.49 \\
\hline & & Tawera spissa & B & 0.51 & 0.01 & 0.87 & 15.85 \\
\hline & & Hemipodus simplex & $\mathrm{P}$ & 0.02 & 0.00 & 1.24 & 18.33 \\
\hline \multirow[t]{5}{*}{$218 \mathrm{C}, 218 \mathrm{~T}$} & \multirow[t]{5}{*}{58.14} & Barantolla sp. & $\mathrm{P}$ & 0.13 & 0.00 & 2.66 & 4.22 \\
\hline & & Notomastus sp. & $\mathrm{P}$ & 0.07 & 0.02 & 2.09 & 7.67 \\
\hline & & Gari stangeri & $\mathrm{B}$ & 1.82 & 0.00 & 0.64 & 10.96 \\
\hline & & Leptomya retiaria & $\mathrm{B}$ & 0.06 & 0.00 & 1.35 & 13.62 \\
\hline & & Maoricolpus roseus roseus & $s \mathrm{G}$ & 1.18 & 0.00 & 0.46 & 16.23 \\
\hline \multirow[t]{5}{*}{$319 \mathrm{C}, 319 \mathrm{~T}$} & \multirow[t]{5}{*}{58.38} & Trochodota dendyi & $\mathrm{E}$ & 0.14 & 0.03 & 1.15 & 3.61 \\
\hline & & Notomastus sp. & $\mathrm{P}$ & 0.09 & 0.12 & 1.15 & 7.07 \\
\hline & & Gari stangeri & B & 0.71 & 0.00 & 0.60 & 10.35 \\
\hline & & Phoronis sp. & $\mathrm{P}$ & 0.03 & 0.05 & 1.36 & 13.37 \\
\hline & & Corbula zelandica & B & 0.13 & 0.00 & 0.76 & 16.02 \\
\hline \multirow[t]{5}{*}{$378 \mathrm{C}, 378 \mathrm{~T}$} & \multirow[t]{5}{*}{55.99} & Trochodota dendyi & $\mathrm{E}$ & 0.10 & 0.11 & 1.04 & 4.00 \\
\hline & & Euchone sp. A & $\mathrm{P}$ & 0.01 & 0.02 & 1.89 & 7.31 \\
\hline & & Gammaridae sp. B & $\mathrm{A}$ & 0.01 & 0.04 & 1.48 & 10.58 \\
\hline & & Polycirrus sp. A & $\mathrm{P}$ & 0.02 & 0.11 & 1.22 & 13.62 \\
\hline & & Notomastus sp. & $\mathrm{P}$ & 0.05 & 0.07 & 1.11 & 16.58 \\
\hline
\end{tabular}

chaetes Owenia petersenae and Prionospio sp., the same genera that have been implicated in recovery from physical disturbances elsewhere (McCall 1977, Maurer et al. 1998). The synchronous abundance patterns in treatment and control plots from late winter onwards, in conjunction with low mean values of biomass in treatment plots even after $N$ and $S$ had recovered to ambient levels, corroborate the view that larval settlement was the primary means of recolonisation. The results of the present study emphasise 
Table 5. Treatment plot specific average dissimilarity $(\delta)$ and species contributing most to $\delta$ for consecutive sampling days. T: Treatment $; 1,6,18$, etc.: sampling day; $y_{1,2}$ : average production of ith species in sample groups 1 and $2 ; \delta_{i}$ : contribution of $i$ th species to $\delta_{i} \operatorname{SD}\left(\delta_{i}\right)$ : standard deviation; $\sum \delta_{i \%}$ : percent cumulative contribution to $\delta_{;}$Taxa: $\mathrm{A}=$ Amphipoda; An $=$ Anthozoa; $\mathrm{B}=$ Bivalvia $\mathrm{C}=$ Crustacea $\mathrm{E}=$ Echinodermata $\mathrm{G}=$ Gastropoda; $\mathrm{P}=$ Polychaeta; $\mathrm{Ph}=$ Phoronida. Only the 5 species contributing most are listed

\begin{tabular}{|c|c|c|c|c|c|c|c|}
\hline Sampling Day & $\delta$ & Species & Taxon & $y_{1}$ & $y_{2}$ & $\delta_{i} / \mathrm{SD}\left(\delta_{i}\right)$ ratio & $\Sigma \delta_{i \%}$ \\
\hline \multirow[t]{5}{*}{$1 \mathrm{~T}, 6 \mathrm{~T}$} & 85.28 & Phoronis sp. & $\mathrm{Ph}$ & 0.02 & 0.02 & 0.82 & 8.74 \\
\hline & & Barantolla sp. & $\mathrm{P}$ & 0.14 & 0.00 & 0.77 & 16.70 \\
\hline & & Carazziella philipensis & $\mathrm{P}$ & 0.00 & 0.01 & 0.80 & 24.34 \\
\hline & & Microphthalamus sp. A & $\mathrm{P}$ & 0.00 & 0.00 & 0.67 & 30.83 \\
\hline & & Armandia muculata & $\mathrm{P}$ & 0.00 & 0.00 & 1.02 & 37.16 \\
\hline \multirow[t]{5}{*}{$6 \mathrm{~T}, 18 \mathrm{~T}$} & 82.52 & Carazziella philipensis & $\mathrm{P}$ & 0.01 & 0.00 & 0.89 & 7.44 \\
\hline & & Armandia muculata & $\mathrm{P}$ & 0.00 & 0.01 & 0.97 & 14.69 \\
\hline & & Phoronis sp. & $\mathrm{Ph}$ & 0.02 & 0.01 & 0.71 & 20.59 \\
\hline & & Corbula zelandica & B & 0.04 & 0.11 & 0.43 & 26.16 \\
\hline & & Capitomastus sp. & $\mathrm{P}$ & 0.00 & 0.00 & 0.72 & 31.06 \\
\hline \multirow[t]{5}{*}{$18 \mathrm{~T}, 39 \mathrm{~T}$} & 80.32 & Armandia muculata & $\mathrm{P}$ & 0.01 & 0.01 & 0.96 & 7.36 \\
\hline & & Gammaridae sp. B & $\mathrm{A}$ & 0.00 & 0.01 & 0.84 & 14.48 \\
\hline & & Carazziella philipensis & $\mathrm{P}$ & 0.00 & 0.00 & 0.97 & 20.73 \\
\hline & & Phoronis sp. & $\mathrm{Ph}$ & 0.01 & 0.02 & 0.66 & 26.80 \\
\hline & & Trochus tiaratus & G & 0.32 & 0.08 & 0.42 & 32.82 \\
\hline \multirow[t]{5}{*}{$39 \mathrm{~T}, 70 \mathrm{~T}$} & 79.77 & Phoronis sp. & $\mathrm{Ph}$ & 0.02 & 0.03 & 0.77 & 8.91 \\
\hline & & Armandia muculata & $\mathrm{P}$ & 0.01 & 0.00 & 1.11 & 16.30 \\
\hline & & Gammaridae sp. B & $\mathrm{A}$ & 0.01 & 0.00 & 0.82 & 23.09 \\
\hline & & Carazziella philipensis & $\mathrm{P}$ & 0.00 & 0.00 & 0.87 & 29.36 \\
\hline & & Corbula zelandica & $\mathrm{B}$ & 0.00 & 0.12 & 0.54 & 35.47 \\
\hline \multirow[t]{5}{*}{$70 \mathrm{~T}, 100 \mathrm{~T}$} & 80.43 & Corbula zelandica & $\mathrm{B}$ & 0.12 & 0.19 & 0.69 & 5.88 \\
\hline & & Gammaridae sp. B & A & 0.00 & 0.02 & 1.16 & 10.88 \\
\hline & & Phoronis sp. & $\mathrm{Ph}$ & 0.03 & 0.00 & 0.67 & 15.20 \\
\hline & & Paguridae spp. juvenile & $\mathrm{C}$ & 0.01 & 0.11 & 0.66 & 19.45 \\
\hline & & Syllidae sp. F & $\mathrm{P}$ & 0.00 & 0.00 & 1.60 & 23.69 \\
\hline \multirow[t]{5}{*}{$100 \mathrm{~T}, 156 \mathrm{~T}$} & 68.24 & Scolanthus sp. & An & 0.00 & 0.03 & 2.53 & 5.58 \\
\hline & & Gammaridae sp. B & $\mathrm{A}$ & 0.02 & 0.05 & 1.01 & 9.39 \\
\hline & & Paguridae spp. juvenile & $\mathrm{C}$ & 0.11 & 0.03 & 0.82 & 13.20 \\
\hline & & Xymene pusillus & $\mathrm{G}$ & 0.00 & 0.04 & 0.86 & 16.51 \\
\hline & & Ruditapes largillierti & $\mathrm{B}$ & 0.00 & 0.01 & 1.23 & 19.83 \\
\hline \multirow[t]{5}{*}{$156 \mathrm{~T}, 218 \mathrm{~T}$} & 61.04 & Serratina charlottae & $\mathrm{B}$ & 0.00 & 0.02 & 1.85 & 3.28 \\
\hline & & Phoronis sp. & $\mathrm{Ph}$ & 0.02 & 0.06 & 1.45 & 6.52 \\
\hline & & Scolanthus sp. & $\mathrm{A}$ & 0.03 & 0.24 & 1.64 & 9.61 \\
\hline & & Xymene pusillus & G & 0.04 & 0.02 & 0.97 & 12.29 \\
\hline & & Trochodota dendyi & $\mathrm{E}$ & 0.00 & 0.02 & 1.20 & 14.91 \\
\hline \multirow[t]{5}{*}{$218 \mathrm{~T}, 319 \mathrm{~T}$} & 56.74 & Barantolla sp. & $\mathrm{P}$ & 0.00 & 0.05 & 1.89 & 3.13 \\
\hline & & Serratina charlottae & B & 0.02 & 0.00 & 1.81 & 6.05 \\
\hline & & Notomastus sp. & $\mathrm{P}$ & 0.02 & 0.12 & 0.95 & 8.88 \\
\hline & & Polycirrus sp. A & $\mathrm{P}$ & 0.02 & 0.05 & 1.21 & 11.46 \\
\hline & & Owenia petersenae & $\mathrm{P}$ & 0.01 & 0.10 & 2.16 & 13.94 \\
\hline \multirow[t]{5}{*}{$319 \mathrm{~T}, 378 \mathrm{~T}$} & 56.92 & Notomastus sp. & $\mathrm{P}$ & 0.12 & 0.07 & 1.22 & 3.57 \\
\hline & & Trochodota dendyi & $\mathrm{E}$ & 0.03 & 0.11 & 1.08 & 6.94 \\
\hline & & Polycirrus sp. A & $\mathrm{P}$ & 0.05 & 0.11 & 1.29 & 10.00 \\
\hline & & Phoronis sp. & $\mathrm{Ph}$ & 0.05 & 0.04 & 1.28 & 12.86 \\
\hline & & Halicarcinus cooki & $\mathrm{C}$ & 0.02 & 0.05 & 1.10 & 15.52 \\
\hline
\end{tabular}

the importance of seasonal recruitment in recovery processes (Zajac \& Whitlach 1982).

\section{Comparison with other studies}

In contrast to many studies on the effects of natural or anthropogenic disturbances on assemblages, a rapid, albeit short-lived, increase in abundances of one or a few opportunistic species immediately post- disturbance, as predicted in succession models (Pearson \& Rosenberg 1976, 1978, Rhoads et al. 1978), was not observed in the present study. Peak abundances of macroinvertebrate opportunists were reported for both natural and experimental small-scale (Norkko \& Bonsdorff 1996), meso-scale (Arntz \& Rumohr 1982, Oliver \& Slattery 1985) and large-scale benthic disturbances (Rosenberg et al. 2002). Such opportunistic responses are triggered when factors that normally inhibit population dynamics of oppor- 
Table 6. Relative dispersion and Index of Multivariate Dispersion (IMD) for control (C) and treatment (T) assemblages of 4th-root transformed production data

\begin{tabular}{|lcccc|}
\hline $\begin{array}{c}\text { Sampling } \\
\text { day }\end{array}$ & $\begin{array}{c}\text { Relative dispersion } \\
\text { Control }\end{array}$ & \multicolumn{2}{c|}{ Pairwise comparisons } \\
Groups & IMD \\
\hline 1 & 0.787 & 1.628 & 1C, 1T & -0.795 \\
6 & 0.616 & 1.595 & $6 \mathrm{C}, 6 \mathrm{~T}$ & -0.875 \\
18 & 0.941 & 1.705 & $18 \mathrm{C}, 18 \mathrm{~T}$ & -0.875 \\
39 & 0.816 & 1.506 & $39 \mathrm{C}, 39 \mathrm{~T}$ & -0.734 \\
70 & 0.577 & 1.643 & $70 \mathrm{C}, 70 \mathrm{~T}$ & -0.892 \\
100 & 0.869 & 1.247 & 100, 100T & -0.483 \\
156 & 1.038 & 1.054 & $156 \mathrm{C}, 156 \mathrm{~T}$ & 0.004 \\
218 & 0.759 & 0.556 & $218 \mathrm{C}, 218 \mathrm{~T}$ & 0.233 \\
319 & 0.554 & 0.732 & $319 \mathrm{C}, 319 \mathrm{~T}$ & -0.219 \\
378 & 0.751 & 0.829 & $378 \mathrm{C}, 378 \mathrm{~T}$ & -0.098 \\
& & & & \\
\hline
\end{tabular}

tunists, such as resource competition and/or amensalistic interactions with bioturbators or tube-builders, are eliminated or restricted following a disturbance (Norkko et al. 2006). The degree of elimination of, or isolation from, these factors depends on the scale and intensity of the disturbance experienced. The absence of an opportunistic response in the present study is surprising, considering the spatial scale of the disturbance and the dominance of opportunistic species in the ambient sediments, some of which have exhibited typical abundance peaks following disturbances (Pearson \& Rosenberg 1978, Rhoads et al. 1978). Yet, the absence of such model-predicted patterns has also been noted elsewhere and was attributed to the timing of the disturbance (Zajac \& Whitlach 1982) and food limitations owing to low organic matter content of the sediment (Thrush et al. 1996). Similarly, no opportunistic abundance peaks were detected following the large-scale toxic blooms in the Skagerrak-Kattegat area (bloom extent ca. $75000 \mathrm{~km}^{2}$; Olsgard 1993) and in Wellington Harbour (ca. $85 \mathrm{~km}^{2}$; Wear \& Gardner 2001, Gardner \& Wear 2006).

In the present study, the slightly higher densities of Owenia petersenae and Barantolla sp. in treatment plots >200 d post-disturbance reflected observed abundance changes following seasonal recruitment in the ambient sediment, but not the model-predicted peak of opportunistic species responding to increased resource levels. We suggest that the absence of shortterm high abundances of opportunistic species was due to a combination of the timing of the disturbance in autumn (i.e. past the main seasonal recruitment peak in Wellington Harbour) and also to a lack of food availability in the sediment. The present study therefore supports the notion that the way disturbances influence soft-sediment macroinvertebrate assemblages depends on various factors, including the spatial scale and intensity of the disturbance, seasonal patterns of recruitment, the local hydrodynamic regime and organic enrichment levels of the sediment. Such a multitude of influences leads to 'a kaleidoscope of post-disturbance changes' (Platt \& Connell 2003) of the disturbed assemblages, and thus it remains difficult to construct general predictions concerning the trajectory of assemblage composition; i.e. simple succession models are likely to be inadequate.

\section{Successional models}

It is nonetheless useful to examine to what extent our results concur with existing models of community recovery. Successional models for marine softsediment macroinvertebrate assemblages predict that the recovery process will exhibit a specific sequence of stages in time and space, whereby each stage is characterised by a typical suite of species well adapted by certain life history traits to the postdisturbance environment (Pearson \& Rosenberg 1976, 1978, Rhoads et al. 1978). Briefly, the successional stage closest to a disturbance, Stage I, is comprised of small and rapidly colonizing species that experience high mortality rates, with a co-occurring high turnover rate of species. The final stage, Stage III, is characterised by a diverse equilibrium or 'climax' assemblage often comprised by relatively stable (albeit low) population densities and consisting of larger, long-lived and often deeper-burrowing organisms similar to those of the pre-disturbed community. Stage II is a more unpredictable and transitory stage, where opportunistic species still dominate, but nonopportunists also occur.

The recovery process in the present study did not fulfil model predictions with regard to the initial successional stage. Yet, when using multivariate analyses such as MDS ordinations, ANOSIM and SIMPER to examine compositional changes during the recovery process, some concordance with the model was observed. In the MDS ordination (Fig. 4), control samples of the entire sampling period grouped together, and this cluster represents the 'equilibrium' or Stage III assemblage of the ambient sedimentalbeit with high abundances of species usually considered typical of Stage I and II assemblages. In the early recovery phase, treatments showed a dramatic change in assemblage composition, as indicated by the 'loop' on the right hand side of the MDS plot and by results of the 1-way ANOSIM and SIMPER analyses, suggesting a high species turnover as predicted by the models for the successional Stages I and II.

After $378 d$, the treatments had approached (but not quite reached) the 'climax' or reference stage of the 
controls in terms of assemblage composition. Similar results were reported from Gullmarsfjord, Sweden, where benthic recovery processes following severe oxygen depletion were analysed by MDS ordination (Fig. 6 in Rosenberg et al. 2002). Despite the differences between the present study and that of Rosenberg et al. (2002), the recovery processes are remarkably similar.

In conclusion, results of multivariate analyses suggest that recovery processes subsequent to an experimental disturbance in a hydrodynamically active soft-sediment site in Wellington Harbour were generally in accordance with current successional models. However, these models are disturbancespecific (organic enrichment; physical disturbance) and paint only a broad picture of recovery as a successional shift from $r$ - to $K$-selected species dominating the community. Consequently, the models' practical uses are restricted in terms of their inability to deliver predictions about recovery times or the end point of recovery following other types of disturbance.

Further investigations into the underlying causes that regulate and influence recovery of subtidal softsediment macroinvertebrate assemblages after mesoand large-scale disturbances such as HABs are clearly needed. A general assessment of the effects of HABs on benthic macroinvertebrate assemblages remains difficult. An $\mathrm{HAB}$ can have strongly variable effects on benthic assemblages, depending on local hydrodynamic conditions and disturbance history of the assemblages (Kröger et al. 2006). Most HABs are stochastical and discrete events, with assemblages being able to recover within 2 to 4 yr depending on the spatial extent and intensity of the bloom (Gjøsæter et al. 2000). However, a scenario is conceivable where, under global warming and increasing coastal pollution, HABs will occur more frequently. If disturbance frequencies become too high (e.g. annual blooms), assemblages may not be able to return to their pre-disturbance state. A consequent shift in assemblage structure leading to the establishment of different, possibly impoverished, assemblages, which are constantly disturbed and cannot reach equilibrium status, would have far-reaching implications on the structure and function of marine food webs.

Acknowledgements. We thank J. Long, R. Williamson and S. Wood (Cawthron Institute) for their help in the field and laboratory. We are grateful to G. Read, N. Bruce (National Institute for Water and Atmospheric Research), B. Marshall (Museum of New Zealand Te Papa Tongarewa) and L. BoltonRitchie (Environment Canterbury) for their help with species identification. This study was part of K.K.'s PhD dissertation and was supported by a Victoria University of Wellington Post-Graduate Targeted Scholarship.

\section{LITERATURE CITED}

Arntz WE, Rumohr H (1982) An experimental study of macrobenthic colonization and succession, and the importance of seasonal variation in temperate latitudes. J Exp Mar Biol Ecol 64:17-45

Bell S, Devlin D (1983) Short-term macrofaunal recolonization of sediment and epibenthic habitats in Tampa Bay, Florida. Bull Mar Sci 33:102-108

Beukema JJ, Flach EC, Dekker R, Starink M (1999) A longterm study of the recovery of the macrozoobenthos on large defaunated plots on a tidal flat in the Wadden Sea. J Sea Res 42:235-254

Brey T (1990) Estimating productivity of macrobenthic invertebrates from biomass and mean individual weight. Meeresforschung 32:329-343

Chang FH, Chiswell SM, Uddstrom MD (2001) Occurrence and distribution of Karenia brevisulcata (Dinophyceae) during the 1998 summer toxic outbreaks on the central east coast of New Zealand. Phycologia 40:215-222

Clarke KR (1993) Non-parametric multivariate analyses of changes in community structure. Aust J Ecol 18:117-143

Clarke KR, Gorley RN (2001) PRIMER v5: User manual/ tutorial Primer-E. Plymouth Marine Laboratory, Plymouth

Clarke KR, Green RH (1988) Statistical design and analysis for a 'biological effects' study. Mar Ecol Prog Ser 46: 213-226

Clarke KR, Warwick RM (2001) Change in marine communities: an approach to statistical analysis and interpretation. Plymouth Marine Laboratory, Plymouth

Clarke KR, Warwick RM, Brown BE (1993) An index showing breakdown of seriation, related to disturbance, in a coralreef assemblage. Mar Ecol Prog Ser 102:153-160

Connell JH, Sousa WP (1983) On the evidence needed to judge ecological stability or persistence. Am Nat 121: 789-824

Dayton PK (1971) Competition, disturbance, and community organization: the provision and subsequent utilization of space in a rocky intertidal community. Ecol Monogr 41: 351-389

Diaz RJ, Rosenberg R (1995) Marine benthic hypoxia: a review of its ecological effects and the behavioural responses of benthic macrofauna. Oceanogr Mar Biol Annu Rev 33:245-303

Dittmann S, Günther CP, Schleier U (1999) Recolonization of tidal flats after disturbance. In: Dittmann S (ed) The Wadden Sea ecosystem stability properties and mechanisms. Springer-Verlag, Berlin, p 175-192

Ford RB, Thrush SF, Probert PK (1999) Macrobenthic colonisation of disturbances on an intertidal sandflat: the influence of season and buried algae. Mar Ecol Prog Ser 191:163-174

Gardner JPA, Wear RG (2006) Subtidal macro-invertebrate community recovery in Wellington Harbour (New Zealand) after a large-scale natural die off. NZ J Mar Freshw Res 40:29-42

Gjøsæter J, Lekve K, Stenseth NC, Leinaas HP and 7 others (2000) A long-term perspective on the Chrysochromulina bloom on the Norwegian Skagerrak coast 1988: a catastrophe or an innocent incident? Mar Ecol Prog Ser 207:201-218

Günther CP (1992) Dispersal of intertidal invertebrates: a strategy to react to disturbances of different scales? J Sea Res 30:45-56

Hallegraeff GM (1993) A review of harmful algal blooms and their apparent global increase. Phycologia 32:79-99

Heath RA (1977) Circulation and hydrology of Wellington Harbour. NZ Oceanogr Surv 12:8 
Johnson RG (1973) Conceptual models of benthic communities. In: Schopf TJM (ed) Models in paleobiology. Freeman Cooper, San Francisco, CA, p 148-159

Kröger K (2003) Recovery of subtidal benthic macroinvertebrate communities following natural and experimental disturbances. PhD thesis, Victoria University of Wellington

Kröger K, Gardner JPA, Rowden AA, Wear RG (2006) Longterm effects of a toxic algal bloom on subtidal softsediment macroinvertebrate communities in Wellington Harbour, New Zealand. Estuar Coast Shelf Sci 67:589-604

Leppäkoski E (1968) Transitory return of the benthic fauna of the Bornholm Basin, after extermination by oxygen insufficiency. Cah Biol Mar 10:163-172

Maurer D, Gerlinger T, Nguyen H (1998) The response of two spionid polychaetes to natural processes and anthropogenic activities on the San Pedro Shelf, California. Ophelia 48:185-206

McCall PL (1977) Community patterns and adaptive strategies of the infaunal benthos of Long Island Sound. J Mar Res 35:221-266

Niemi GJ, DeVore P, Detenbeck N (1990) Overview of case studies on recovery of aquatic ecosystems from disturbance. Environ Manag 14:571-588

Norkko A, Bonsdorff E (1996) Rapid zoobenthic community responses to accumulations of drifting algae. Mar Ecol Prog Ser 131:143-157

Norkko A, Rosenberg R, Thrush, SF, Whitlach RB (2006) Scale- and intensity-dependant disturbance determines the magnitude of opportunistic response. J Exp Mar Biol Ecol 330:195-207

Oliver JS, Slattery PN (1985) Destruction and opportunity on the sea floor: effects of gray whale feeding. Ecology 66: 1965-1975

Olsgard F (1993) Do toxic algal blooms affect subtidal softbottom communities? Mar Ecol Prog Ser 102:269-286

Olsgard F, Somerfield PJ, Carr MR (1997) Relationships between taxonomic resolution and data transformations in analyses of a macrobenthic community along an established pollution gradient. Mar Ecol Prog Ser 149:173-181

O'Neill RV (1999) Recovery in complex ecosystems. J Aquat Ecosyst Stress Recov 6:181-187

Pearson TH, Rosenberg R (1976) A comparative study of the effects on the marine environment of wastes from cellulose industries in Scotland and Sweden. Ambio 5:77-79

Pearson TH, Rosenberg R (1978) Macrobenthic succession in relation to organic enrichment and pollution of the marine environment. Oceanogr Mar Biol Annu Rev 16:229-311

Pickett STA, White PA (1985) The ecology of natural disturbance and patch dynamics. Academic Press, Orlando, FL

Platt W, Connell J (2003) Natural disturbances and directional replacement of species. Ecol Monogr 73:507-522

Rhoads DC (1974) Organisms-sediment relations on the muddy seafloor. Oceanogr Mar Biol Annu Rev 12:263-300

Rhoads DC, McCall PL, Yingst JY (1978) Disturbance and production on the estuarine seafloor. Am Sci 66:577-586

Rosenberg R, Agrenius S, Hellman B, Nilsson HC, Norling K (2002) Recovery of marine benthic habitats and fauna in a Swedish fjord following improved oxygen conditions. Mar Ecol Prog Ser 234:43-53

Editorial responsibility: Howard Browman (Associate Editorin-Chief), Storebø, Norway
Saiz-Salinas J (1997) Evaluation of adverse biological effects induced by pollution in the Bilbao Estuary (Spain). Environ Pollut 96:351-359

Santos SL, Simon JL (1980) Marine soft-bottom community establishment following annual defaunation: larval or adult recruitment? Mar Ecol Prog Ser 2:235-241

Schratzberger M, Warwick RM (1998) Effects of physical disturbance on nematode communities in sand and mud: a microcosm experiment. Mar Biol 130:643-650

Smith CR, Brumsickle SJ (1989) The effects of patch size and substrate isolation on colonization modes and rates in an intertidal sediment. Limnol Oceanogr 34:1263-1277

Snelgrove PVR (1994) Hydrodynamic enhancement of invertebrate larval settlement in microdepositional environments: colonization tray experiments in a muddy habitat. J Exp Mar Biol Ecol 176:149-166

Thistle D (1981) Natural physical disturbance and communities of marine soft bottoms. Mar Ecol Prog Ser 6: 223-228

Thrush SF, Whitlach RB (2001) Recovery dynamics in benthic communities: balancing detail with simplification. In: Reise K (ed) Ecological comparisons of sedimentary shores, Vol 151. Springer-Verlag, Berlin, p 297-316

Thrush SF, Whitlach RB, Pridmore RD, Hewitt JE, Cummings VJ, Wilkinson MR (1996) Scale-dependent recolonization: the role of sediment stability in a dynamic sandflat habitat. Ecology 77:2472-2487

Van der Linden WJM (1967) A textural analysis of Wellington Harbour sediments. NZ J Mar Freshw Res 1:26-37

Warwick RM, Clarke KR (1993) Increased variability as a symptom of stress in marine communities. J Exp Mar Biol Ecol 172:215-226

Warwick RM, Clarke KR, Gee JM (1990) The effect of disturbance by soldier crabs, Mictyris platycheles H. Milne Edwards, on meiobenthic community structure. J Exp Mar Biol Ecol 135:19-33

Wear RG, Gardner JPA (2001) Biological effects of the toxic algal bloom of February and March 1998 on the benthos of Wellington Harbour, New Zealand. Mar Ecol Prog Ser 218:63-76

Whitlach RB, Lohrer AM, Thrush SF, Pridmore RD, Hewitt JE, Cummings VJ, Zajac RN (1998) Scale-dependent benthic recolonization dynamics: life stage-based dispersal and demographic consequences. Hydrobiologia 375/376: $217-226$

Whitlach RB, Lohrer AM, Thrush SE (2001) Scale-dependent recovery of the benthos: effects of larval and post-larval stages. In: Aller RC, Aller J, Woodin SA (eds) Organismsediment-interaction, Vol 21. University of South Carolina, Columbia, p 181-197

Zajac RN (1999) Understanding the sea floor landscape in relation to impact assessment and environmental management in coastal marine sediments. In: Gray JS, Ambrose W Jr, Szaniawska A (eds) Biogeochemical cycling and sediment ecology. Kluwer Academic Publishers, Dordrecht, p 211-227

Zajac RN, Whitlach RB (1982) Responses of estuarine infauna to disturbance. II. Spatial and temporal variation of succession. Mar Ecol Prog Ser 10:15-27

Submitted: December 14, 2005; Accepted: April 3, 2006

Proofs received from author(s): October 4, 2006 